Prepared in cooperation with Albany Utilities

\title{
Groundwater Quality and Groundwater Levels in Dougherty County, Georgia, April 2019 Through March 2020
}

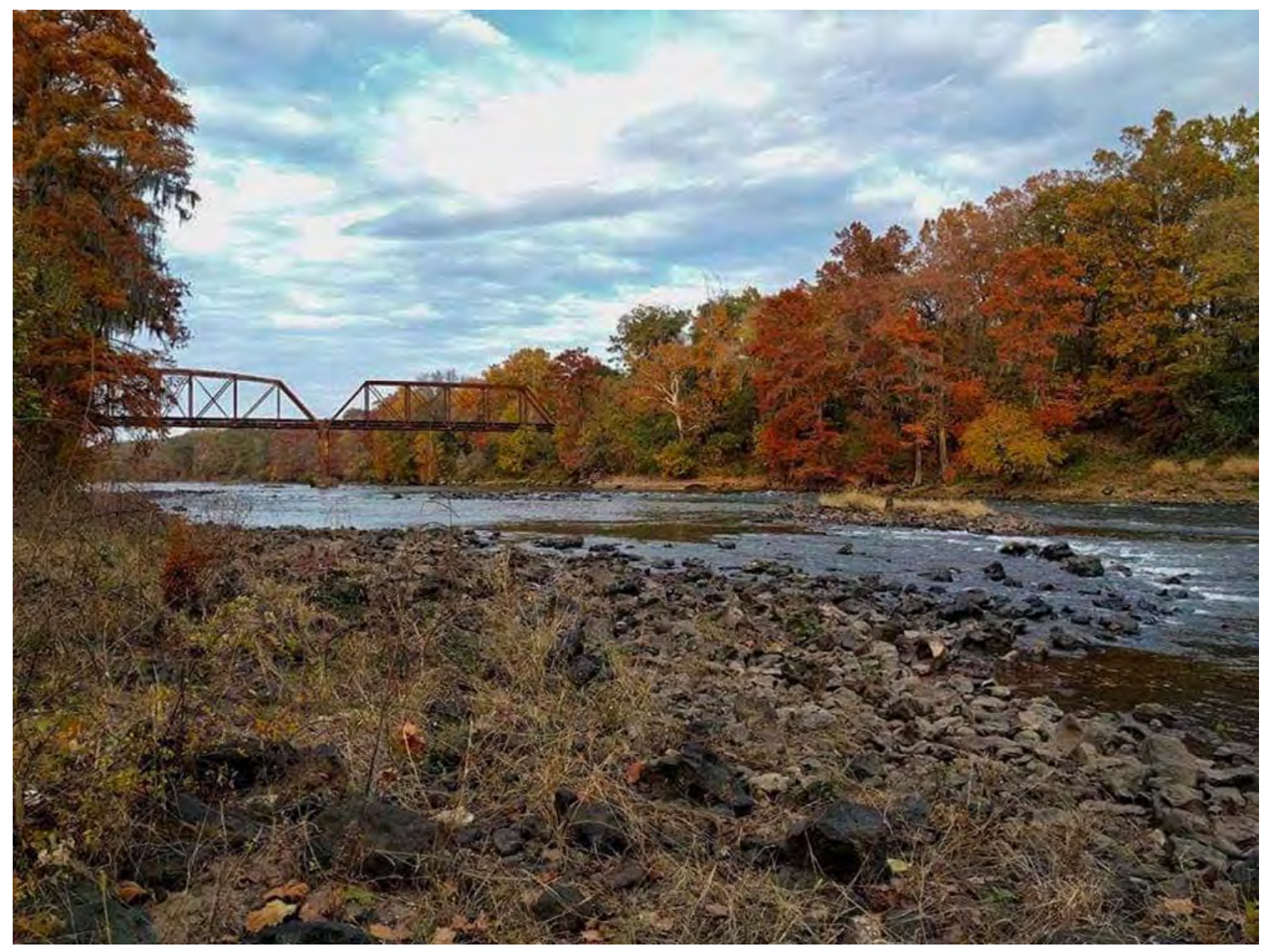

Open-File Report 2020-1120 
Cover. Flint River, Albany, Georgia. Photograph by Debbie Gordon. 


\section{Groundwater Quality and Groundwater Levels in Dougherty County, Georgia, April 2019 Through March 2020}

By Debbie W. Gordon

Prepared in cooperation with Albany Utilities

Open-File Report 2020-1120 


\title{
U.S. Department of the Interior \\ DAVID BERNHARDT, Secretary
}

\author{
U.S. Geological Survey \\ James F. Reilly II, Director
}

U.S. Geological Survey, Reston, Virginia: 2020

For more information on the USGS - the Federal source for science about the Earth, its natural and living resources, natural hazards, and the environment—visit https://www.usgs.gov or call 1-888-ASK-USGS.

For an overview of USGS information products, including maps, imagery, and publications, visit https://store.usgs.gov/.

Any use of trade, firm, or product names is for descriptive purposes only and does not imply endorsement by the U.S. Government.

Although this information product, for the most part, is in the public domain, it also may contain copyrighted materials as noted in the text. Permission to reproduce copyrighted items must be secured from the copyright owner.

Suggested citation:

Gordon, D.W., 2020, Groundwater quality and groundwater levels in Dougherty County, Georgia, April 2019 through March 2020: U.S. Geological Survey Open-File Report 2020-1120, 12 p., https://doi.org/10.3133/ofr20201120.

ISSN 0196-1497 (print)

ISSN 2331-1258 (online) 


\section{Acknowledgments}

The author wishes to thank Albany Utilities for working with the U.S. Geological Survey to collect hydrologic data. Thanks also goes out to the homeowners, farmers, and businesses that allowed access to their property.

This project would not happen without assistance from U.S. Geological Survey colleagues. Alan Cressler was fundamental in groundwater-sample collection. John McCranie collected groundwater-level measurements. 



\section{Contents}

Acknowledgments ……...................................................................................................................

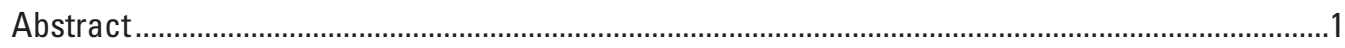

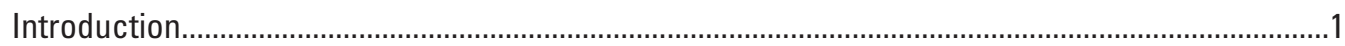

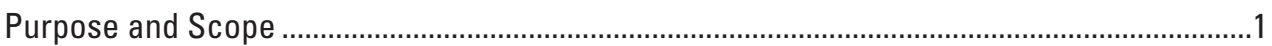

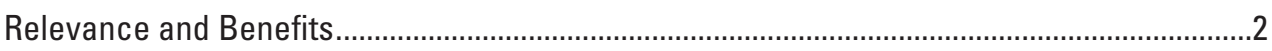

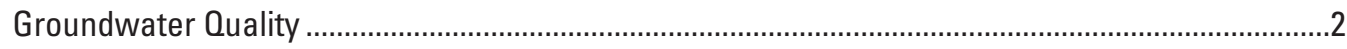

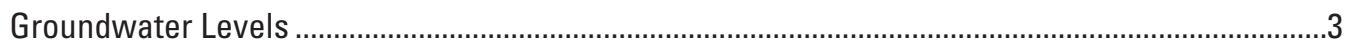

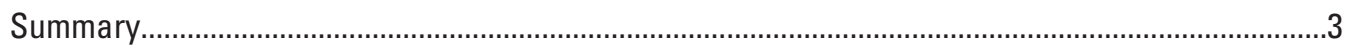

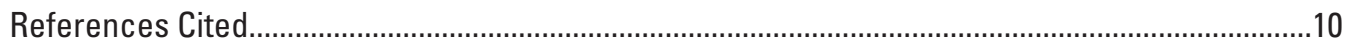

\section{Figures}

1. Map showing wells and streamgages with continuous groundwater and surface-water-level recorders, Dougherty County, Georgia.............................................6

2. Generalized stratigraphy and water-bearing units underlying Albany and surrounding areas, southwestern Georgia .

3. Map showing nitrate plus nitrite as nitrogen concentrations in the Upper Floridan aquifer, 2020, and wells tested for pesticides during 2008-11 and 2020, Albany area, Georgia ..

4. Graph showing concentrations and trends of nitrate plus nitrite as nitrogen for select wells and the Flint River, 1998-2020, Albany area of Georgia

5. Graphs showing concentrations and linear regression trend line of nitrate plus nitrite as nitrogen for select wells, 1998-2020, Albany area of Georgia

6. Map showing potentiometric surface and groundwater flow directions of the Upper Floridan aquifer, Dougherty County, Georgia, using groundwater levels from select wells, December 2019

7. Hydrographs for selected wells in Dougherty County, Georgia, April 2019 through March 2020

\section{Conversion Factors}

U.S. customary units to International System of Units

\begin{tabular}{lcll}
\hline \multicolumn{1}{c}{ Multiply } & By & To obtain \\
\hline \multicolumn{3}{c}{ Length } & \\
\hline inch (in.) & 2.54 & centimeter (cm) \\
inch (in.) & 25.4 & millimeter (mm) \\
foot (ft) & 0.3048 & meter (m) \\
mile (mi) & 1.609 & kilometer $(\mathrm{km})$ \\
mile, nautical (nmi) & 1.852 & kilometer $(\mathrm{km})$ \\
yard (yd) & 0.9144 & meter $(\mathrm{m})$ \\
\hline
\end{tabular}

Hydraulic gradient

foot per mile $(\mathrm{ft} / \mathrm{mi})$

0.1894 meter per kilometer $(\mathrm{m} / \mathrm{km})$ 


\begin{tabular}{lcc}
\hline Multiply & By & To obtain \\
\hline & Hydraulic gradient & \\
\hline foot per foot $(\mathrm{ft} / \mathrm{ft})$ & 1 & meter per meter $(\mathrm{m} / \mathrm{m})$ \\
\hline
\end{tabular}

International System of Units to U.S. customary units

\begin{tabular}{lll}
\hline \multicolumn{1}{c}{ Multiply } & By & \multicolumn{1}{c}{ To obtain } \\
\hline & Length & \\
\hline centimeter $(\mathrm{cm})$ & 0.3937 & inch (in.) \\
millimeter $(\mathrm{mm})$ & 0.03937 & inch (in.) \\
meter $(\mathrm{m})$ & 3.281 & foot (ft) \\
kilometer $(\mathrm{km})$ & 0.6214 & mile (mi) \\
kilometer $(\mathrm{km})$ & 0.5400 & mile, nautical (nmi) \\
meter $(\mathrm{m})$ & 1.094 & yard (yd) \\
\hline
\end{tabular}

meter $(\mathrm{m})$

Hydraulic gradient

meter per kilometer $(\mathrm{m} / \mathrm{km}) \quad 5.27983$ foot per mile $(\mathrm{ft} / \mathrm{mi})$

meter per meter $(\mathrm{m} / \mathrm{m}) \quad 1 \quad$ foot per foot $(\mathrm{ft} / \mathrm{ft})$

Temperature in degrees Celsius $\left({ }^{\circ} \mathrm{C}\right)$ may be converted to degrees Fahrenheit $\left({ }^{\circ} \mathrm{F}\right)$ as follows: ${ }^{\circ} \mathrm{F}=\left(1.8 \times{ }^{\circ} \mathrm{C}\right)+32$.

Temperature in degrees Fahrenheit $\left({ }^{\circ} \mathrm{F}\right)$ may be converted to degrees Celsius $\left({ }^{\circ} \mathrm{C}\right)$ as follows: ${ }^{\circ} \mathrm{C}=\left({ }^{\circ} \mathrm{F}-32\right) / 1.8$.

\section{Datum}

Vertical coordinate information is referenced to the National Geodetic Vertical Datum of 1929 (NGVD 29).

Horizontal coordinate information is referenced to North American Datum of 1983 (NAD 83).

\section{Supplemental Information}

Concentrations of chemical constituents in water are given in milligrams per liter (mg/L) or micrograms per liter ( $\mu \mathrm{g} / \mathrm{L})$.

\section{Abbreviation}

USGS U.S. Geological Survey 


\title{
Groundwater Quality and Groundwater Levels in Dougherty County, Georgia, April 2019 Through March 2020
}

\author{
By Debbie W. Gordon
}

\section{Abstract}

The Upper Floridan aquifer is the uppermost, reliable aquifer in southwest Georgia. The aquifer lies on top of the Claiborne, Clayton, and Cretaceous aquifers, all of which exhibited water level declines in the 1960s and 1970s. The U.S. Geological Survey has been working cooperatively with Albany Utilities to monitor groundwater quality and availability in these aquifers since 1977.

During January 2020, nine wells were sampled — six for anions, metals, and nitrate plus nitrite as nitrogen, and three for anions, metals, and pesticides. Nitrate plus nitrite as nitrogen concentrations ranged from 2.4 milligrams per liter $(\mathrm{mg} / \mathrm{L})$ to $10.4 \mathrm{mg} / \mathrm{L}$, and no pesticides were detected. Nitrate plus nitrite as nitrogen concentrations in well 12L277, open to the Upper Floridan aquifer, have been above the U.S. Environmental Protection Agency Maximum Contaminant Level of $10 \mathrm{mg} / \mathrm{L}$ for nitrates in drinking water since 2014.

Flow direction in the Upper Floridan aquifer is to the south and toward the Flint River. Water levels varied during the past year above and below period of record median values. Water levels in the Upper Floridan aquifer were primarily above median levels. Water levels in the Claiborne aquifer were above median levels, whereas water levels in the Clayton and Cretaceous aquifers were below median levels.

\section{Introduction}

The U.S. Geological Survey (USGS) has been working with Albany Utilities, Dougherty County, Georgia (fig. 1), to monitor groundwater quality and availability since 1977. Heavy pumping since the 1960s and 1970s from the Claiborne, Clayton, and Upper Cretaceous aquifers, which underlie the Upper Floridan aquifer, has resulted in substantial water-level declines in the Albany area (fig. 2; Hicks and others, 1981). To meet increasing demands, Albany Utilities developed a large well field that was put online during October 2003. The well field is made up of eight supply wells that primarily withdraw water from the Upper Floridan aquifer. The Upper Floridan aquifer is a highly productive and porous limestone aquifer and is the uppermost reliable groundwater source in the area. Because of the karstic landscape and the local recharge to the aquifer, water quality may be affected by local and regional land use. A zone of nitrate contamination was detected during 1997 in the Upper Floridan aquifer southwest of Albany, Georgia, by the Dougherty County Health Department. The detection prompted an investigation of the potential sources of the elevated nitrate (Wenner and Reyher, 1999). Water from 12 percent of the wells sampled had nitrate concentrations above the 10 milligrams per liter (mg/L) U.S. Environmental Protection Agency Maximum Contaminant Level for drinking water (Wenner and Reyher, 1999; U.S. Environmental Protection Agency, 2000). Each of the contaminated wells are open to the Upper Floridan aquifer, which supplies water for most domestic and irrigation wells in the southwest Albany area.

\section{Purpose and Scope}

The purpose of this report is to provide a summary of data collected during a 1-year period (April 2019 through March 2020). The report includes an overview of groundwater conditions and a summary of water-quality data collected during the year, and nitrate trends since 1998. This report is the latest in a series of reports summarizing this program (Gordon, 2008, 2009; Gordon and others, 2012). The objectives of the study were to (1) augment the current level of understanding of the hydrogeologic framework of the Upper Floridan aquifer in the Albany area of southwest Georgia, (2) monitor water quality in the Upper Floridan aquifer as pumping patterns and land-use activities change, and (3) monitor water-level fluctuations in the four aquifers used in the area. These objectives were met by the following tasks:

- water-quality monitoring near the southwestern Albany area, including annual nitrate monitoring;

- groundwater-level monitoring of 14 continuous wells (fig. 1) and periodic measurement of water levels in about 25-50 wells annually; and 
- maintaining the USGS National Water Information System database, which includes groundwater, surfacewater, and water-quality data.

Samples also were collected for the analysis of the occurrence of pesticides during January 2020 from Albany Utilities' supply wells 12L010, 12L015, and 12L018 (fig. 3). These wells draw water from the Claiborne and Clayton aquifers, below the Upper Floridan aquifer.

\section{Relevance and Benefits}

An important part of the USGS mission is to provide reliable, impartial, and timely scientific information to manage and understand the water resources of the Nation through a program of shared efforts with Federal, State, and local partners. The USGS, through these partnerships, seeks to solve real-world problems by developing tools to improve the application of hydrologic information to the management of water resources while ensuring that USGS information and tools are available to all potential users (U.S. Geological Survey, 2020b).

The study supports the USGS Water Strategic Science Plan, 2012-2022 (Evenson and others, 2012) with emphasis on evaluating the effects of land use and population increases on water resources including drinking water availability, water quality, and hydrologic system management. The data will provide water managers with information needed for groundwater-resources development in the Albany, Georgia, area.

\section{Groundwater Quality}

Samples have been collected annually-typically after the growing season in the fall or early winter since 1998 - from as many as 19 wells in the Upper Floridan aquifer and the Flint River for water-quality analyses. The samples have primarily been analyzed for nitrate plus nitrite as nitrogen concentrations due to historically high concentrations of nitrate. Nitrate plus nitrite as nitrogen concentrations have been low at Flint River site 02352560 compared to concentrations in the Upper Floridan aquifer, even though groundwater from the aquifer generally discharges into the River (figs. 3 and 4). During January 2020, nine wells were sampled according to standard USGS methods; six for anions, metals, and nitrate plus nitrite as nitrogen, and three for anions, metals, and pesticides (U.S. Geological Survey, variously dated). During January 2020, nitrate plus nitrite as nitrogen concentrations ranged from $2.4 \mathrm{mg} / \mathrm{L}$ in well $12 \mathrm{~L} 344$ to $10.4 \mathrm{mg} / \mathrm{L}$ in well $12 \mathrm{~L} 277$ (figs. 3 and 4). Currently (2020), nitrate plus nitrite as nitrogen concentrations in most of the wells continue to indicate a slight, gradual increase with time (fig. 4). Nitrate plus nitrite as nitrogen trend lines were fit using simple linear regression. Statistical significance was determined for the trend lines using the $p$-value of the regression fit with a criterion of less than 0.05 indicating significance (StatsDirect Ltd, 2000). Of the 19 wells, 10 were determined to have significant nitrate plus nitrite as nitrogen trends -8 wells have significant increasing trends, and 2 wells have significant decreasing trends. Four of the wells with significant nitrate plus nitrite as nitrogen trends are shown in figure 5.

Well 12L277, downgradient from the previously described area of elevated nitrate plus nitrite as nitrogen concentrations and upgradient from the well field (fig. 3), has an increasing nitrate plus nitrite as nitrogen trend of $0.20 \mathrm{mg} / \mathrm{L}$ per year. The nitrate plus nitrite as nitrogen concentrations in well 12L277 range from $6.3 \mathrm{mg} / \mathrm{L}$ during 2002 to $12.9 \mathrm{mg} / \mathrm{L}$ during 2014 (fig. 5), and have consistently been greater than the U.S. Environmental Protection Agency Maximum Contaminant Level of $10 \mathrm{mg} / \mathrm{L}$ (U.S. Environmental Protection Agency, 2000) for nitrate in drinking water since 2014. Well 12L344 has a decreasing nitrate plus nitrite as nitrogen trend of $0.10 \mathrm{mg} / \mathrm{L}$ per year. Results indicate that nitrate plus nitrite as nitrogen was $6 \mathrm{mg} / \mathrm{L}$ in 1998 but has been at or below $3 \mathrm{mg} / \mathrm{L}$ since 2001 (fig. 5). This well is adjacent to an area of past organic fertilizer application (Wenner and Reyher, 1999; Warner and Lawrence, 2005). The decreasing trend may indicate that the nitrate plus nitrite as nitrogen source is having less of an effect on groundwater at this well. Nitrate plus nitrite as nitrogen concentrations in well 12L348 have been increasing at a rate of $0.14 \mathrm{mg} / \mathrm{L}$ per year since 1998 , and results indicate that the highest nitrate plus nitrite as nitrogen concentration of $9.6 \mathrm{mg} / \mathrm{L}$ was during January 2020. Well 12L373 has a positive nitrate plus nitrite as nitrogen trend of $0.09 \mathrm{mg} / \mathrm{L}$ per year; however, the nitrate plus nitrite as nitrogen concentration was $8.7 \mathrm{mg} / \mathrm{L}$ during January 2020, down from the highest concentration of $9.6 \mathrm{mg} / \mathrm{L}$ during 2015 (fig. 5).

The T.H. Agriculture \& Nutrition Co. (Albany Plant) was placed on the EPA National Priorities List in 1989 because of contaminated groundwater, sediment, and soil (fig. 3). Two former pesticide formulation facilities were operated at the site from the 1950s and 1960s, respectively, until the 1980s (U.S. Environmental Protection Agency, 2018). Onsite monitoring results from October 2017 indicate that the following contaminants of concern remain above the remediation goal for groundwater in the residuum, upper and intermediate limestone of the Upper Floridan aquifer: Ethylene Dibromide, aldrin, dieldrin, Dichlorodiphenyltrichloroethane, alphaBenzene hexachloride, beta-Benzene hexachloride, toxaphene, and xylene (U.S. Environmental Protection Agency, 2018). During 2008, USGS employees collected samples from two Albany Utilities' municipal supply wells, both screened in the Claiborne and Clayton aquifers (wells 12L010 and 12L018; fig. 3). The samples were analyzed to determine if pesticides may have migrated into the underlying Claiborne and Clayton aquifers and into the Albany municipal water supply. Results indicate that the sample collected from well 12L010 yielded no detectable pesticides, and the sample collected from well 12L018 had low concentrations of p,p'-methoxychlor, three orders of magnitude below the U.S. Environmental Protection 
Agency Maximum Contaminant Level of $0.04 \mathrm{mg} / \mathrm{L}$

(U.S. Environmental Protection Agency, 2000; Gordon, 2009). USGS sampled well 12L018 for pesticides during 2009, 2010, and 2011, and no contaminants were detected. During January 2020, wells 12L010 and 12L018 were sampled and analyzed again for pesticides, along with well 12L015 (also screened in the Claiborne and Clayton aquifers; fig. 3). Results indicate that the samples contained no detectable pesticides. Water-quality data may be obtained from the USGS National Water Information System at https://nwis.waterdata.usgs.gov/ usa/nwis/qw.

\section{Groundwater Levels}

Water-level data are measured from selected wells open to the Upper Floridan aquifer on an annual basis. During December 2019, water levels were collected from 28 wells and ranged from about 135 feet above the National Geodetic Vertical Datum of 1929 in the southern part of the study area to about 195 feet above the National Geodetic Vertical Datum of 1929 in the northern part of the study area (fig. 6). The hydraulic gradient of the Upper Floridan aquifer generally slopes southward and toward the Flint River at a rate of about 5.9 feet per mile or 0.001 foot per foot. The Flint River is a major discharge area for the aquifer; however, when the river is high, the gradient may reverse in the southern part of the study area.

Water levels are continuously monitored in five aquifers. Below is a summary of groundwater levels within these aquifers during a 1-year period (April 2019 through March 2020) relative to period of record median water levels (https://www.usgs.gov/centers/sa-water/science/groundwatermonitoring-program-albany-dougherty-county-area; U.S. Geological Survey, 2020c). An example of a hydrograph from each aquifer (not including the surficial aquifer), along with the period of record median water levels for the well, are presented in figure 7 (the well hydrograph is shown in blue and the median daily statistic for the period of record is shown in orange). More information on current groundwater levels in Georgia is on the USGS Groundwater Conditions of Georgia web page at https://www2.usgs.gov/water/southatlantic/ga/ infodata/gwconditions/index.php (U.S. Geological Survey, 2020a). The following water-level observations were made during April 2019 through March 2020:

- Water levels in the surficial aquifer at well 12L376 ranged from 19.5 feet below land surface during March 2020 to 30 feet below land surface during December 2019 (https://nwis.waterdata.usgs.gov).

- Water levels in the Upper Floridan aquifer were primarily above median levels (fig. $7 A$ ), except in wells 12K014, 12K180, and 12L373 where water levels were close to median levels before rising in December 2019.

- Water levels in the Claiborne aquifer were above median levels (fig. 7B).
- Water levels in the Clayton aquifer were below median levels (fig. 7C).

- Water levels in the Cretaceous aquifer system were below median levels (fig. 7D).

\section{Summary}

Groundwater samples were collected from nine wells. During January 2020, nitrate plus nitrite as nitrogen concentrations ranged from $2.4 \mathrm{mg} / \mathrm{L}$ to $10.4 \mathrm{mg} / \mathrm{L}$. Upper Floridan aquifer well 12L277 has had nitrate plus nitrite as nitrogen concentrations between 10.4 and $12.9 \mathrm{mg} / \mathrm{L}$ since 2014. No pesticides were detected in the samples.

Groundwater in the Upper Floridan aquifer generally flows southward and toward the Flint River. During April 2019 through March 2020, water levels in the Upper Floridan and Claiborne aquifers were generally above median levels based on the period of record. Water levels in the Clayton and Cretaceous aquifers were below median levels.

\section{References Cited}

Clarke, J.S., Faye, R.E., and Brooks, R., 1984, Hydrogeology of the Clayton aquifer of southwest Georgia: Georgia Geologic Survey Hydrologic Atlas 13, 6 pls.

Evenson, E.J., Orndorff, R.C., Blome, C.D., Böhlke, J.K., Hershberger, P.K., Langenheim, V.E., McCabe, G.J., Morlock, S.E., Reeves, H.W., Verdin, J.P., Weyers, H.S., and Wood, T.M., 2012, Strategic directions for U.S. Geological Survey water science, 2012-2022-Observing, understanding, predicting, and delivering water science to the Nation: U.S. Geological Survey Open-File Report 2012-1066, 42 p., https://doi.org/10.3133/ofr20121066.

Gordon, D.W., 2008, Ground-water conditions and studies in the Albany area of Dougherty County, Georgia, 2007: U.S. Geological Survey Open-File Report 2008-1328, 49 p., available online only at https://pubs.usgs.gov/of/ 2008/1328/.

Gordon, D.W., 2009, Groundwater conditions and studies in the Albany area of Dougherty County, Georgia, 2008: U.S. Geological Survey Open-File Report 2009-1244, 54 p., https://doi.org/10.3133/ofr20091244.

Gordon, D.W., Painter, J.A., and McCranie, J.M., 2012, Hydrologic conditions, groundwater quality, and analysis of sink hole formation in the Albany area of Dougherty County, Georgia, 2009: U.S. Geological Survey Scientific Investigations Report 2012-5018, 60 p., https://doi.org/ 10.3133/sir20125018. 
Hicks, D.W., Gill, H.E., and Longsworth, S.A., 1987, Hydrogeology, chemical quality, and availability of ground water in the Upper Floridan aquifer, Albany area, Georgia: U.S. Geological Survey Water-Resources Investigations Report 87-4145, 52 p., accessed August 23, 2016, at https://pubs.usgs.gov/wri/wri87-4145/pdf/wrir87-4145.pdf.

Hicks, D.W., Krause, R.E., and Clarke, J.S., 1981, Geohydrology of the Albany area, Georgia: Georgia Geologic Survey Information Circular 57, 31 p.

StatsDirect Ltd, 2000, P Values, accessed July 8, 2020, at https://www.statsdirect.com/help/basics/p_values.htm.

U.S. Environmental Protection Agency, 2000, Maximum contaminant levels (Subpart B of part 141, National Primary Drinking-Water Regulations): U.S. Code of Federal Regulations, Title 40, parts 100-149, revised as of July 1, 2000, p. 334-560, accessed October 14, 2020, at https://www.epa.gov/ground-water-and-drinking-water/ national-primary-drinking-water-regulations.

U.S. Environmental Protection Agency, 2018, Fourth five-year review report for T.H. Agriculture and Nutrition Co. (Albany Plant) Superfund site, Dougherty County, Georgia, July 2018: accessed June 15, 2020, at https://cumulis.epa.gov/supercpad/SiteProfiles/index.cfm? fuseaction $=$ second.scs\&id $=0401428 \& d o c=Y \&$ colid $=$ 31577 \&region $=04 \&$ type $=$ SC .

U.S. Geological Survey, [variously dated], National Field Manual for the Collection of water Quality Data, USGS Techniques and Methods, Book 9, chapters A0-A10, accessed September 29, 2020 at https://www.usgs.gov/ mission-areas/water-resources/science/national-fieldmanual-collection-water-quality-data-nfm?qt-science center_objects $=0 \# q t-s c i e n c e \_c e n t e r \_o b j e c t s$.
U.S. Geological Survey, 2020a, Groundwater Conditions of Georgia, accessed June 3, 2020, at https://www2.usgs.gov/ water/southatlantic/ga/infodata/gwconditions/index.php.

U.S. Geological Survey, 2020b, USGS Cooperative Matching Funds, accessed July 23, 2020, at https://www.usgs.gov/ mission-areas/water-resources/science/usgs-cooperativematching-funds?qt-science_center_objects $=0 \# q$ t-science center_objects.

U.S. Geological Survey, 2020c, Groundwater monitoringAlbany-Dougherty County, Georgia, accessed July 24, 2020, at https://www.usgs.gov/centers/sa-water/science/ groundwater-monitoring-program-albany-doughertycounty-area.

Warner, D., and Lawrence, S.J., 2005, Ground-water flow and water quality of the Upper Floridan aquifer, southwestern Albany area, Georgia, 1998-2001: U.S. Geological Survey Scientific Investigations Report 2005-5047, 77 p., https://pubs.usgs.gov/sir/2005/5047/.

Wenner, D.B., and Reyher, S.M., 1999, Investigation of the source of nitrate contamination in the Upper Floridan aquifer near Albany, Georgia, in Hatcher, K.J., ed., Proceedings of the 1999 Georgia Water Resources Conference, held March 20-22, 1999, at The University of Georgia: Institute of Ecology, The University of Georgia, Athens, Ga., p. 507-510. 
Figures 1-7 


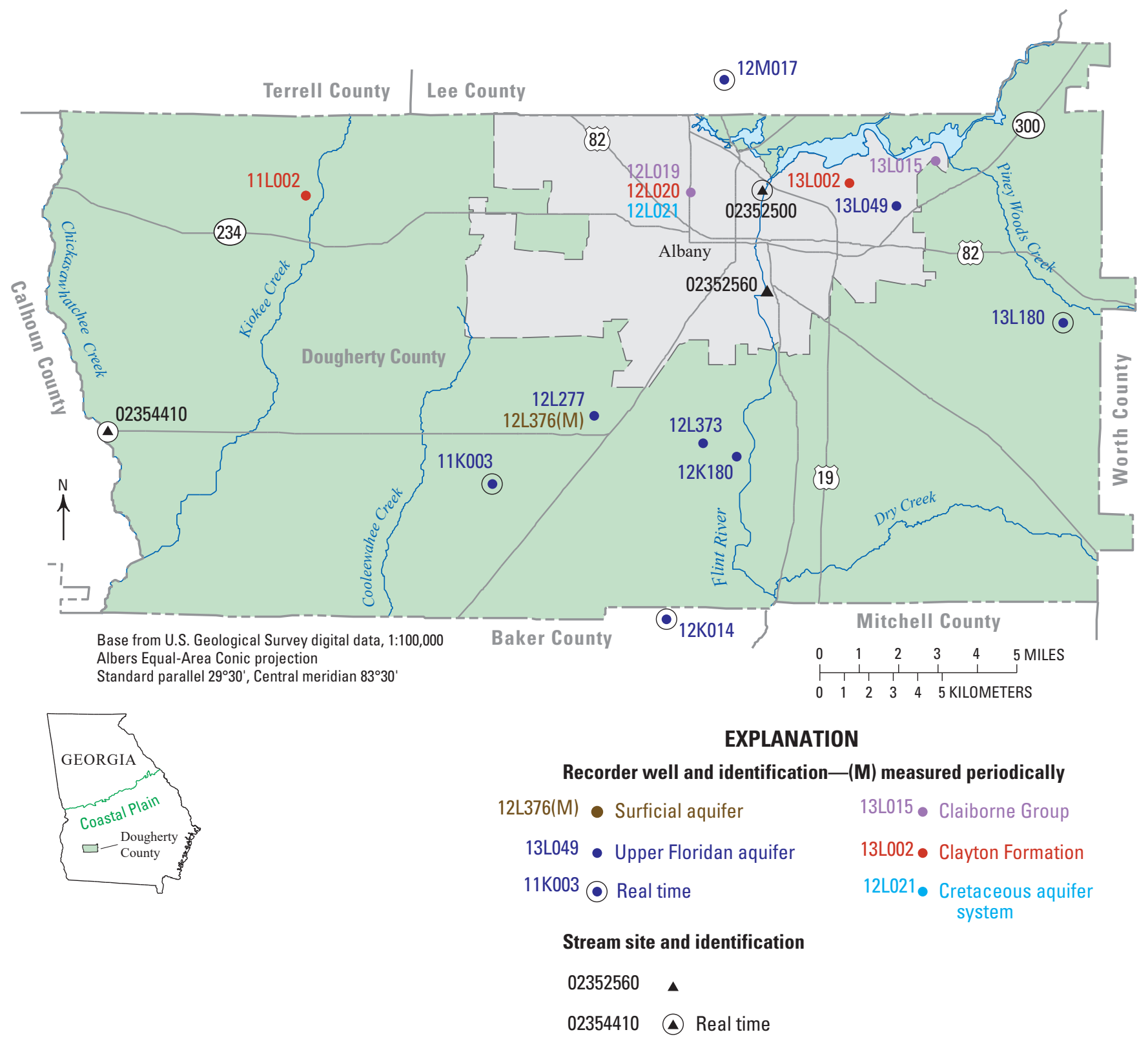

Figure 1. Wells and streamgages with continuous groundwater and surface-water-level recorders, Dougherty County, Georgia. Horizontal coordinate information is referenced to the North American Datum of 1983. 


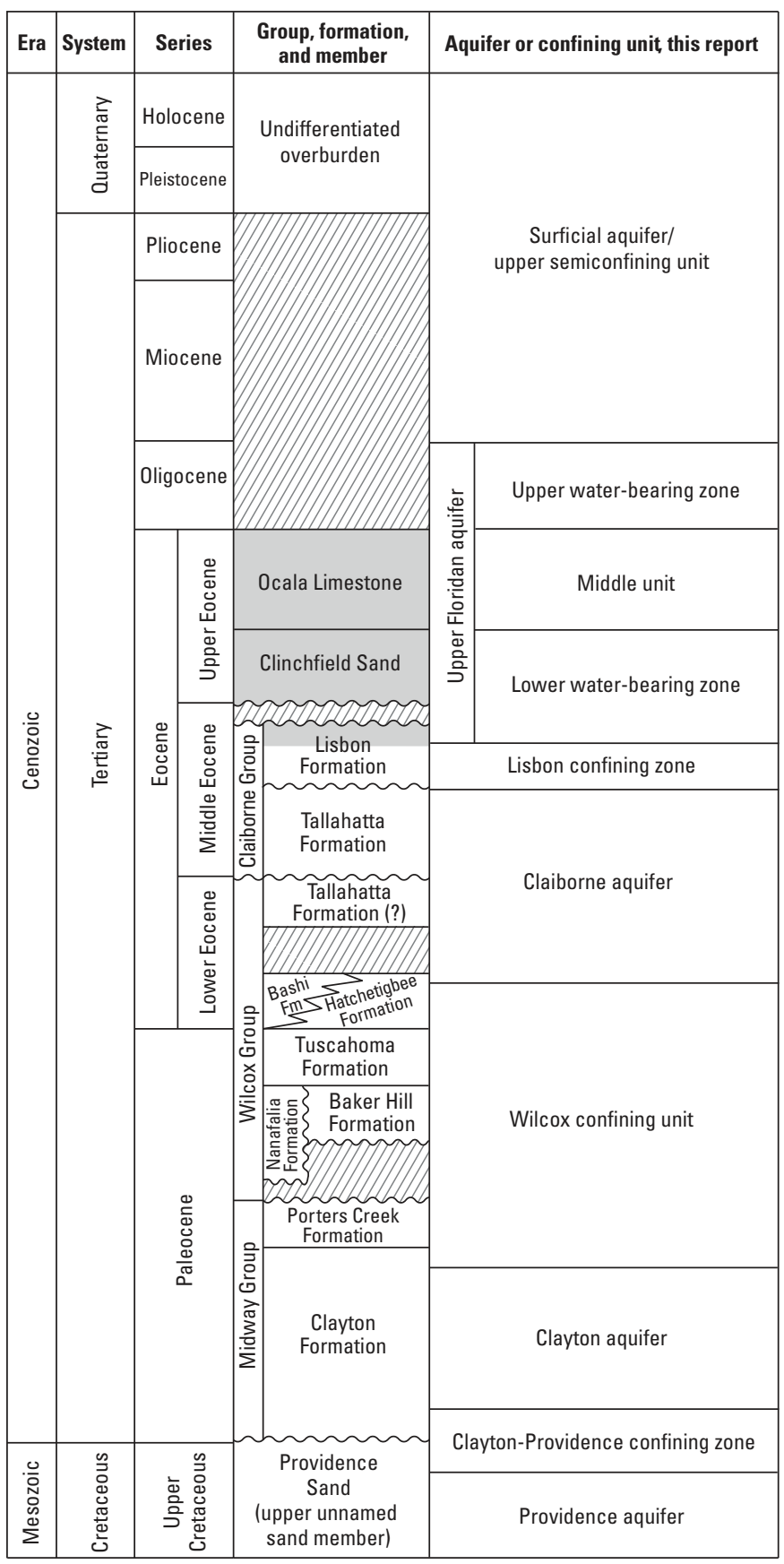

\section{EXPLANATION}

Sediments composing Upper Floridan aquifer

\section{VII/ Missing rocks}

Figure 2. Generalized stratigraphy and water-bearing units underlying Albany and surrounding areas, southwestern Georgia. Lower Eocene and older modified from Clarke and others, 1984; middle Eocene and younger modified from Hicks and others, 1987; Fm, formation. 


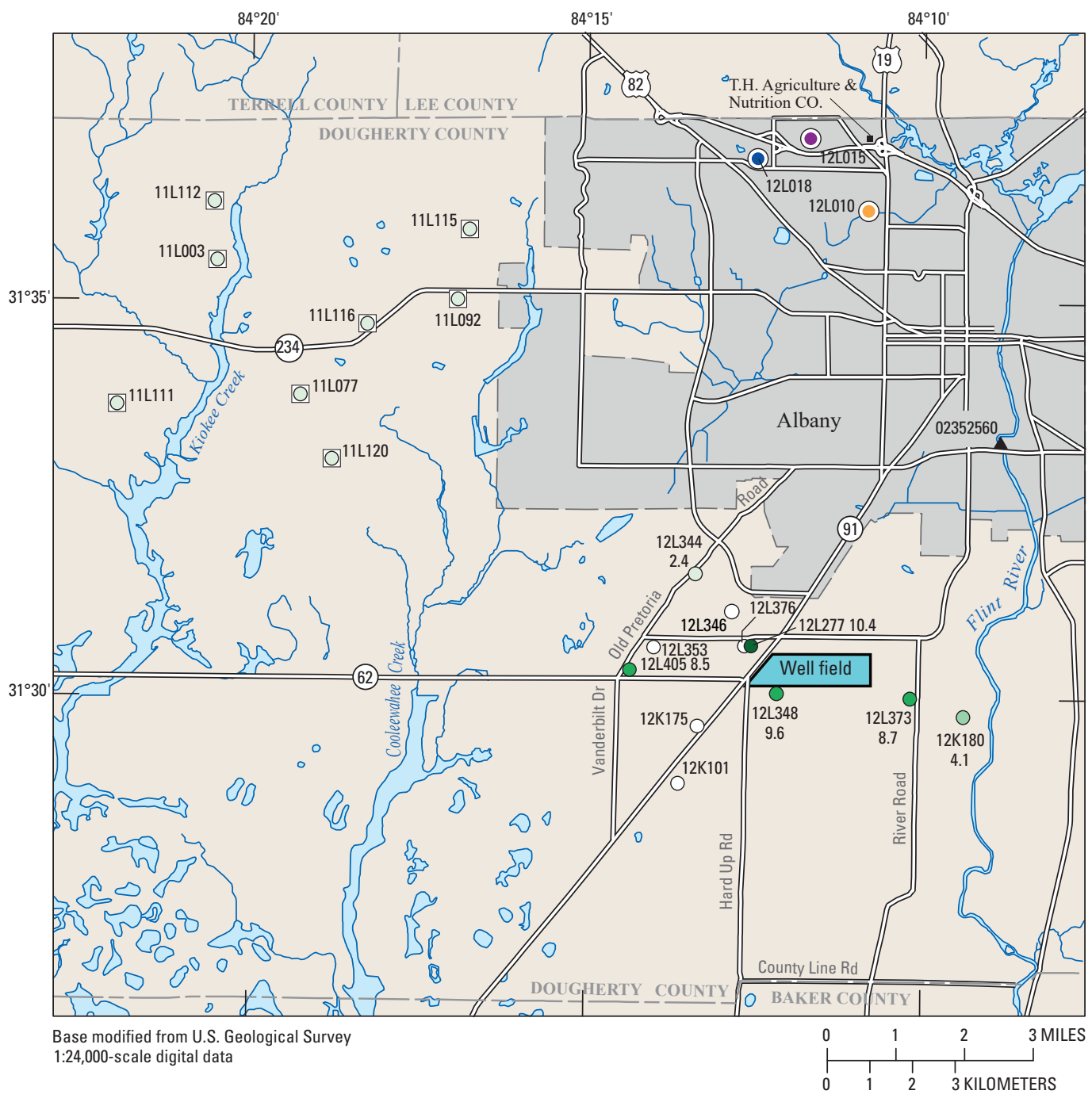

EXPLANATION

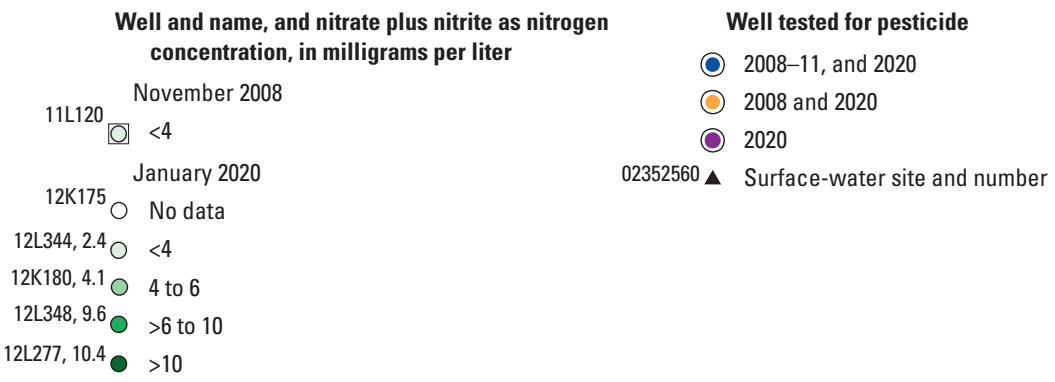

Figure 3. Nitrate plus nitrite as nitrogen concentrations in the Upper Floridan aquifer, 2020, and wells tested for pesticides during 2008-11 and 2020, Albany area, Georgia. All wells completed in Upper Floridan aquifer except for well 12L376, which is completed in surficial aquifer, and wells 12L010, 12L015, and 12L018, which are completed in the Claiborne and Clayton aquifers. Horizontal coordinate information is referenced to North American Datum of 1983. 


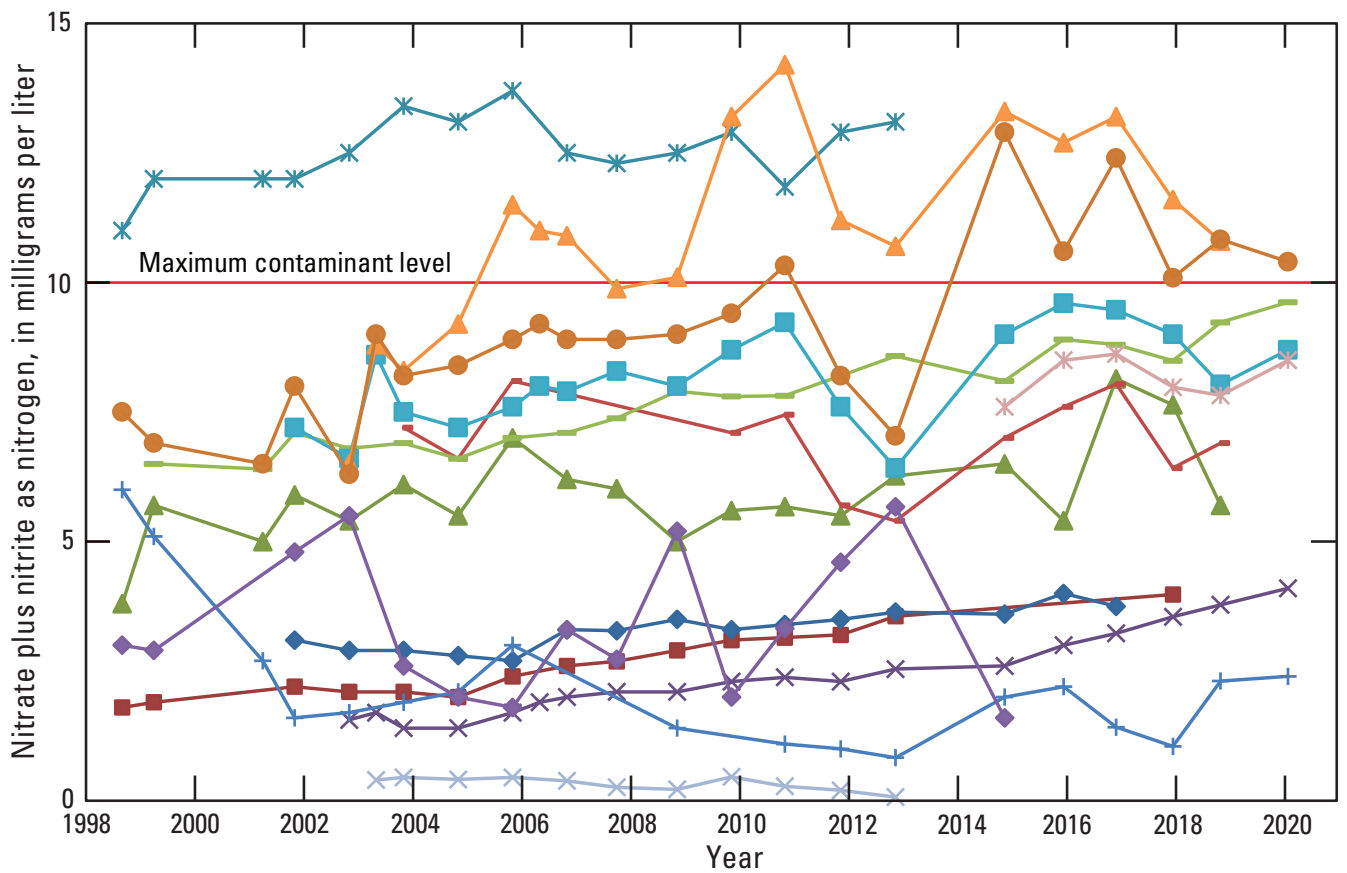

EXPLANATION

Well name and line of nitrate plus nitrite as nitrogen concentration

$\longrightarrow$ - $12 \mathrm{~K} 101$

$\multimap 12 \mathrm{~K} 129$

$-12 \mathrm{~K} 175$

$\rightarrow 12 \mathrm{~K} 180$

* 12L061

- - 12L277

+12 L344

- $12 \mathrm{~L} 346$

$-12 \mathrm{~L} 348$

$\multimap 12 \mathrm{~L} 350$

$-12 \mathrm{~L} 373$

$-12 \mathrm{~L} 376$

* 12L405

$\times 02352560$

Figure 4. Concentrations and trends of nitrate plus nitrite as nitrogen for select wells and the Flint River, 1998-2020, Albany area of Georgia. 

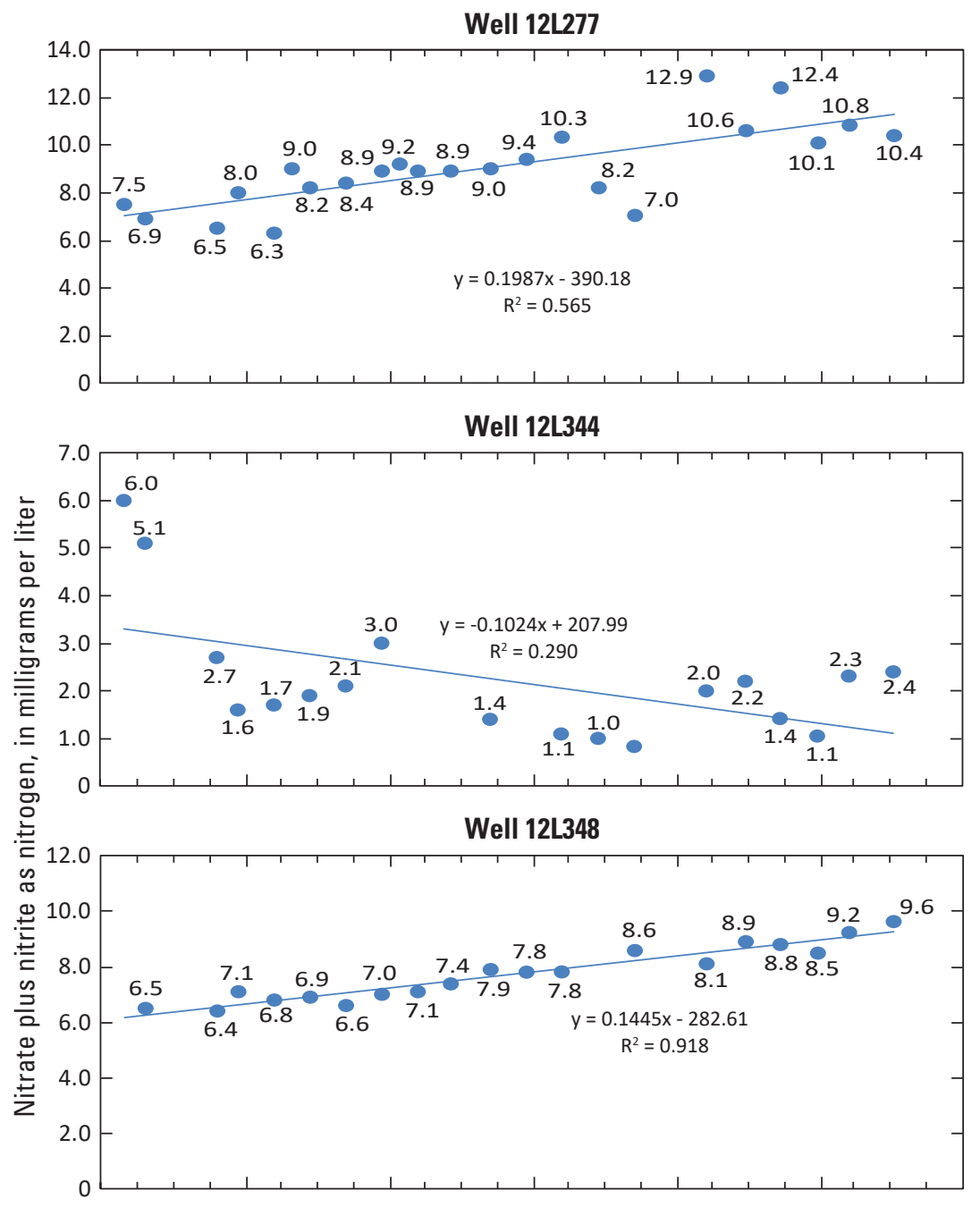

Well 12L373

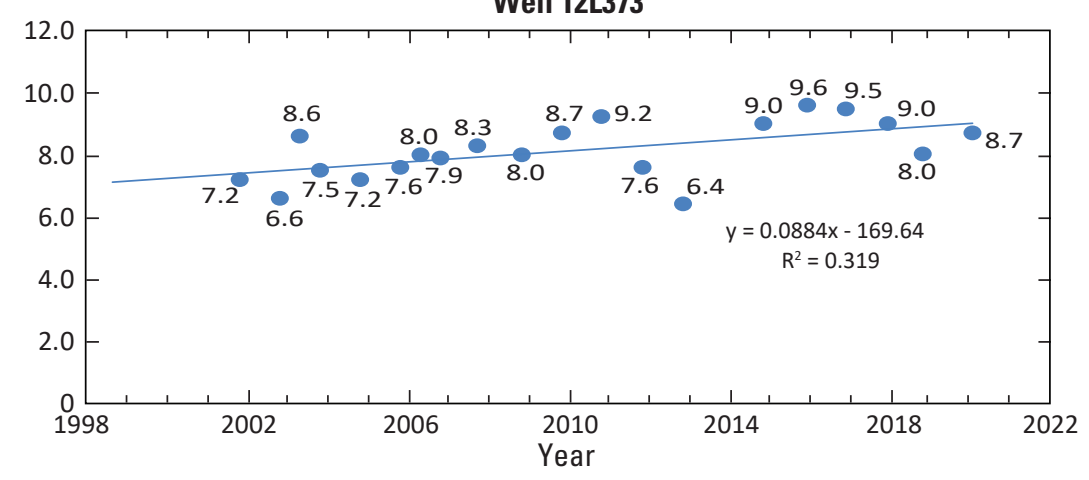

Figure 5. Concentrations and linear regression trend line of nitrate plus nitrite as nitrogen for select wells, 1998-2020, Albany area of Georgia. 


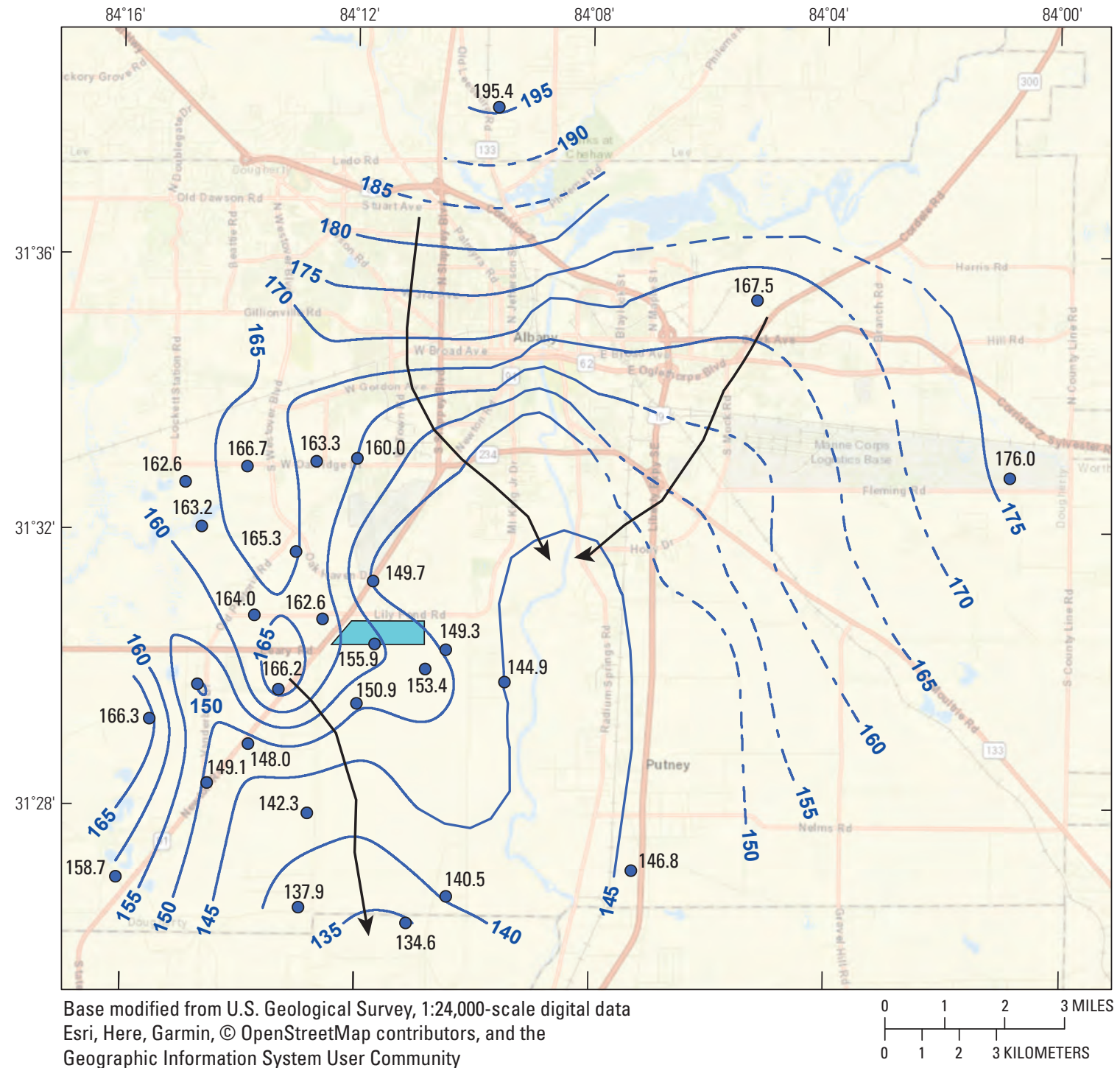

Geographic Information System User Community

\section{EXPLANATION}

Well field

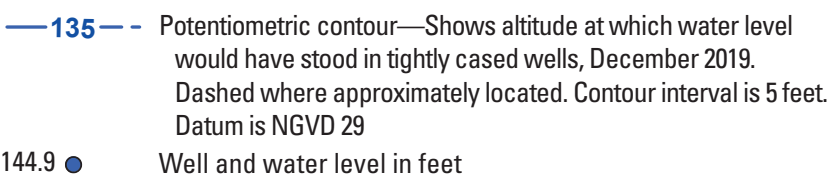

144.9 Well and water level in feet

Figure 6. Potentiometric surface and groundwater flow directions of the Upper Floridan aquifer, Dougherty County, Georgia, using groundwater levels from select wells, December 2019. Vertical coordinate information is referenced to the National Geodetic Vertical Datum of 1929. Horizontal coordinate information is referenced to North American Datum of 1983. 

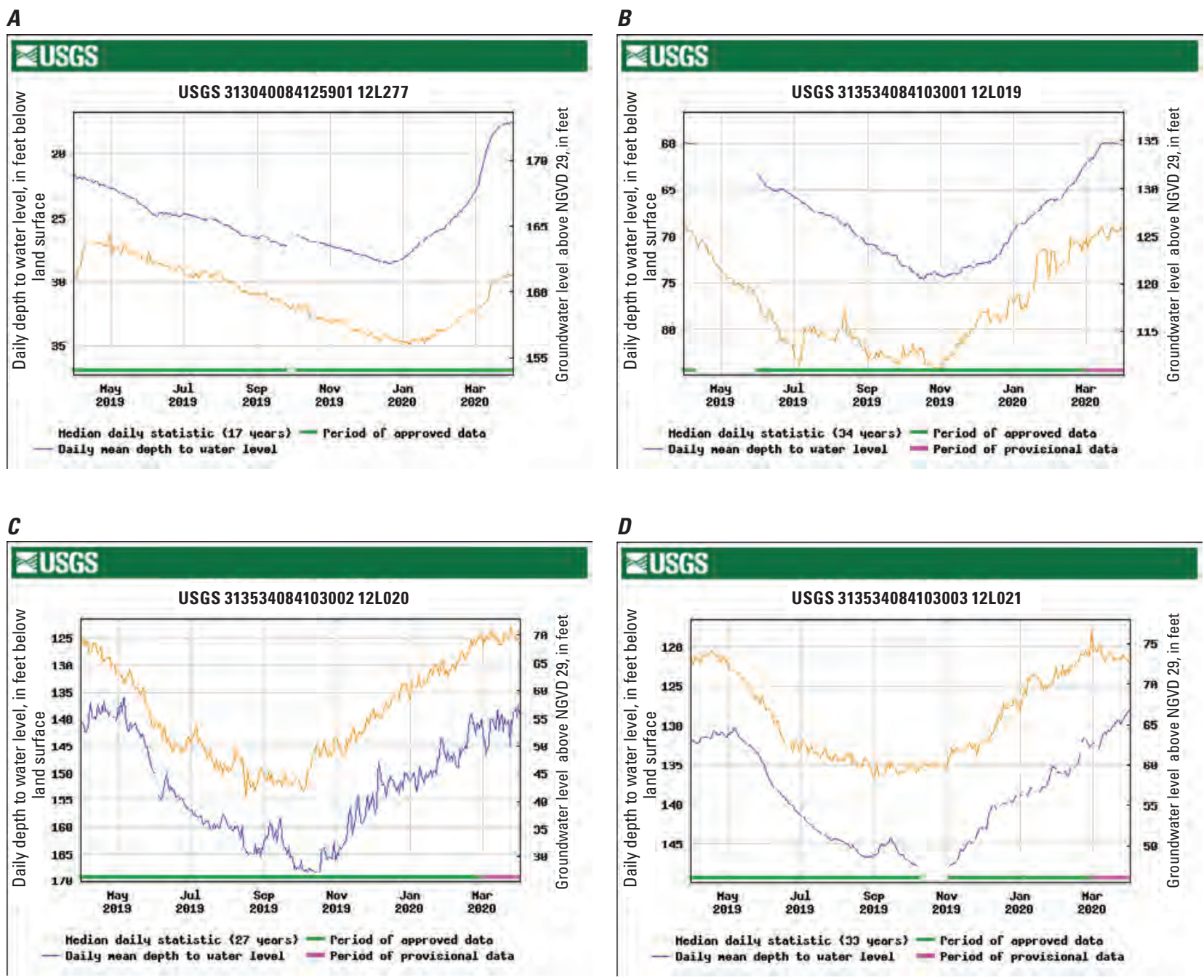

Figure 7. Hydrographs for selected wells in Dougherty County, Georgia, April 2019 through March 2020. A, well 12L277 in the Upper Floridan aquifer; $B$, well 12L019 in the Claiborne aquifer; $C$, well 12L020 in the Clayton aquifer; and D, well 12L021 in the Cretaceous aquifer system. Vertical coordinate information is referenced to the National Geodetic Vertical Datum of 1929 (NGVD 29); U.S. Geological Survey, USGS. 
For more information about this publication, contact:

Director, South Atlantic Water Science Center 1770 Corporate Drive, Suite 500

Norcross, GA 30093

https://www.usgs.gov/centers/sa-water

Prepared by the USGS Science Publishing Network Reston Publishing Service Center 


\section{$\frac{\mathbb{2}}{3}$}

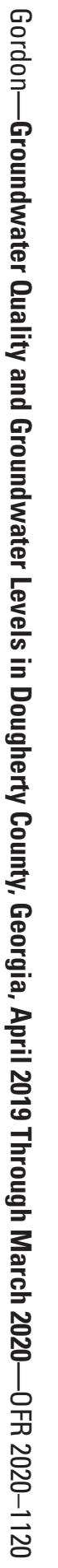

